

Open Access

Asian Australas. J. Anim. Sci.

Vol. 29, No. 10 : 1483-1489 October 2016

http://dx.doi.org/10.5713/ajas.15.0855

www.ajas.info

pISSN 1011-2367 elSSN 1976-5517

\title{
Ileal Amino Acid Digestibility of Broken Rice Fed to Postweaned Piglets with or without Multicarbohydrase and Phytase Supplementation
}

\author{
J. C. Dadalt, C. Gallardo, G. V. Polycarpo, F. E. L. Budiño ${ }^{1}$, A. Rogiewicz ${ }^{2}$, \\ D. A. Berto ${ }^{3}$, and M. A. Trindade Neto* \\ Department of Animal Nutrition and Production, University of Sao Paulo, Pirassununga, SP 13635-900, Brazil
}

\begin{abstract}
Most of amino acid (AA) digestibility values for feed ingredients are obtained using pigs cannulated in the distal ileum. The ileal-cannulated pig model uses pigs older than six weeks due to difficulties related to implanting the T-cannula in distal ileum of younger pigs and complications during the post-surgical recovery. However, to properly formulate the diet of weaned pigs, the nutritive value of feed ingredients should be determined with younger pigs. Thus, 25 weaned pigs were used to determine the apparent total tract digestibility (ATTD) of nutrients, energy, and apparent ileal digestibility (AID) and standardized ileal digestibility (SID) ileal AA digestibility of broken rice (BR), with or without multicarbohydrase (MC) and phytase (Phy) supplementation. Piglets were weaned at $23 \mathrm{~d}$ of age and individually housed in digestibility cages until $45 \mathrm{~d}$ of age. The trial consisted of $7 \mathrm{~d}$ of adaptation to the experimental diets and $3 \mathrm{~d}$ of excreta (feces and urine) collection. Ileal digesta was collected at slaughter (about 6 weeks of age). A completely randomized experimental design was used to determine the effects of MC and Phy. Reference diets (RD, 5\% casein) was replaced by $30 \%$ of BR with or without MC, Phy, or MC+Phy. The RD was used to quantify endogenous AA losses. BR with Phy supplied had increased the ATTD of dry matter $(\mathrm{p}<0.05)$ and SID of histidine $(\mathrm{p}=0.05)$, arginine, leucine, lysine, valine, alanine, and proline $(\mathrm{p}<0.05)$. BR with $\mathrm{MC}$ had been increased digestible energy and protein and SID for histidine $(\mathrm{p}<0.05)$. There was no interaction between Phy and MC on the BR nutrient digestibilities. Standardized amino acid digestibilities of BR, without enzymes, were lower than those values reported in the literature. The MC and Phy improved the digestibility of some nutrients and energy of BR in postweaned piglet diets. (Key Words: Amino Acids Digestibility, Broken Rice, Exogenous Enzymes, Metabolism, Nutrient Balance, Weaned Pigs)
\end{abstract}

\section{INTRODUCTION}

Most of amino acid (AA) digestibility values for various feed ingredients are measured with pigs fitted with a Tcannula at the distal ileum. The studies use pigs not younger than 6 weeks due to difficulties related to implanting the Tcannula on distal ileum and complications during the post-

\footnotetext{
* Corresponding Author: M. A. Trindade Neto. Tel: +55-1935654228, Fax: +55-19-35654264, E-mail: messiastn@usp.br

${ }^{1}$ Animal Science Institute, IZ, Nova Odessa, SP 13460-000, Brazil.

2 Department of Animal Science, University of Manitoba, Winnipeg, MB R3T 2N2, Canada.

${ }^{3}$ Department of Animal Science, UNESP, Botucatu, SP 18618970, Brazil.

Submitted Oct. 20, 2015; Revised Dec. 14, 2015; Accepted Mar. 4, 2016
}

surgical recovery. Thus, the nutrient digestibility for weaned pigs might be overestimated because the feed formulation for weaned pigs is still based on digestibility data obtained from animals in different physiological stage of gut development.

Rice is one of the main energy sources for human nutrition and its use in pig diets is limited by price and market availability (Vicente et al., 2008). Broken rice (BR), by-product of smooth or polished rice production, has a similar nutrient contents to corn in terms of protein $(7.90 \%$ vs $8.24 \%$ ) and metabolizable energy (ME) (14.70 vs 14.21 $\mathrm{MJ} / \mathrm{kg}$ ) (NRC, 2012) as fed basis. Thus, BR has potential to be an alternative to corn in piglet diet. According to Mateos et al. (2006) piglets from 21 to $41 \mathrm{~d}$ of age, fed rice, had higher food intake and average daily gain than piglets fed maize but feed conversion ratio was not affected. However, 
the information about standardized ileal digestibility (SID) of AA of BR for weaned pigs remains limited (NRC, 2012).

The exogenous enzyme supplementation has become a common practice when feed ingredients containing high fiber and high phytate phosphorus are used. Phytase can alleviate the negative effects associated with phytic acid by release of $\mathrm{P}$ from phytate. Carbohydrases have potential to enhance the nutritive value of the diet eliminating the nutrient encapsulating effect of the cell walls and therefore improving energy and AAs availabilities. AAs availability can be improved by enzymes due to their ability to the hydrolysis of certain types of carbohydrate-protein linkages (Slominski, 2011). Dietary supplementation with enzymes degrading the non-starch polysaccharides can not only enhance the cell wall solubility but have the potential of improving phytase efficacy by elevating the release of $\mathrm{P}$ from phytate (Kim et al., 2005).

The experiments were conducted to determine the apparent total tract digestibility (ATTD) of nutrients and energy, and apparent ileal digestibility (AID) and standardized ileal digestibility (SID) of AA of BR in piglet fed diets supplemented with multicarbohydrase (MC) or phytase (Phy), alone or in combination.

\section{MATERIALS AND METHODS}

All research methods and procedures were approved by the ethics and animal experimentation committee at the University of Sao Paulo (project 2843/2012), and followed all the requirements in relation to animal welfare.

\section{Experimental design, diets and enzymes}

The BR sample used for the current study was obtained from Hi-Tech Feeds; Pelotas, Rio Grande do Sul, Brazil. For the four experimental treatments, reference diet (RD, $5 \%$ casein) was replaced by $30 \%$ of test ingredient (BR) with or without the $\mathrm{MC}(\mathrm{BR}+\mathrm{MC})$; phytase $(\mathrm{BR}+\mathrm{Phy})$ or combination of both enzymes (BR+MC+Phy), respectively. A RD was used in AID and SID calculations and a reference corn dry-whey milk-powder diet was used for ATTD determination. Twenty-five $23 \mathrm{~d}$ old weaned pigs with average body weight (BW) of $6 \mathrm{~kg}$ were housed individually in metabolism crates with transparent sides and woven flooring. Pigs were allotted to the four experimental and one reference dietary treatments (Table 1) for a total of five pigs per treatment. A completely randomized experimental design was used to determine the effects of enzymes on ATTD of nutrients and energy; and AID and SID of AA. The ferric oxide $\left(\mathrm{Fe}_{2} \mathrm{O}_{3}\right)$ was added to experimental diets (ATTD of nutrients determination) at $0.25 \%$ to determine the collection time-frame by the appearance of marked feces. Chromium oxide $\left(\mathrm{Cr}_{2} \mathrm{O}_{3}\right)$ was used as an indigestible marker $(0.3 \%$ of the diet) for the
Table 1. Feed composition and nutrient content of reference and experimental diets for piglets ${ }^{1}$

\begin{tabular}{|c|c|c|c|c|}
\hline \multirow{2}{*}{ Items } & \multicolumn{2}{|c|}{ ATTD } & \multicolumn{2}{|c|}{ SID } \\
\hline & $\mathrm{R}$ & $\mathrm{BR}$ & $\mathrm{R}$ & $\mathrm{BR}$ \\
\hline \multicolumn{5}{|l|}{ Ingredients (\%) } \\
\hline Corn & 61.65 & 43.14 & - & - \\
\hline Corn starch & 5.00 & 3.50 & 41.56 & 29.09 \\
\hline Broken rice & - & 30.00 & - & 30.00 \\
\hline Soybean oil & 1.98 & 1.40 & 3.13 & 2.19 \\
\hline Dry whey & 15.00 & 10.50 & - & - \\
\hline Skim milk powder & 10.00 & 7.00 & - & - \\
\hline Dextrose & - & - & 21.00 & 14.70 \\
\hline Lactose & - & - & 20.00 & 14.00 \\
\hline Casein & - & - & 5.00 & 3.50 \\
\hline Choline, $96 \%$ & 0.01 & 0.01 & 0.01 & 0.01 \\
\hline Potassium chloride & - & - & 1.04 & 0.73 \\
\hline Sodium bicarbonate & 0.43 & 0.30 & 1.04 & 0.73 \\
\hline Dicalcium phosphate & 1.71 & 1.19 & 3.01 & 2.11 \\
\hline Limestone & 0.54 & 0.38 & 0.22 & 0.15 \\
\hline Chromium oxide & - & - & 0.30 & 0.21 \\
\hline Zinc oxide & 0.35 & 0.25 & 0.35 & 0.25 \\
\hline Vitamin Premix ${ }^{a}$ & 0.10 & 0.07 & 0.10 & 0.07 \\
\hline Mineral premix ${ }^{b}$ & 0.10 & 0.07 & 0.10 & 0.07 \\
\hline Cellulose & 3.00 & 2.10 & 3.00 & 2.10 \\
\hline Antioxidant & 0.01 & 0.01 & 0.12 & 0.08 \\
\hline Flavores & 0.12 & 0.08 & 0.02 & 0.01 \\
\hline Total & 100 & 100 & 100 & 100 \\
\hline \multicolumn{5}{|l|}{ Calculated composition (\%) } \\
\hline Dry matter & 90.41 & - & 93.84 & - \\
\hline Metabolizable energy $(\mathrm{MJ} / \mathrm{kg})$ & 14.19 & - & 13.94 & - \\
\hline Crude protein & 9.01 & - & 4.26 & - \\
\hline Calcium & 0.85 & - & 0.85 & - \\
\hline Digestible P & 0.45 & - & 0.45 & - \\
\hline Sodium & 0.28 & - & 0.28 & - \\
\hline Chlorine & 0.31 & - & 0.49 & - \\
\hline Potassium & 0.61 & - & 0.52 & - \\
\hline Linoleic acid & 2.21 & - & 1.65 & - \\
\hline
\end{tabular}

${ }^{1} \mathrm{R}$, reference diet; BR, broken rice. BR replaced $30 \%$ of reference diet, with or without multicarbohydrase $(200 \mathrm{~g} / \mathrm{ton})$; phytase $(50 \mathrm{~g} / \mathrm{ton})$ and multicarbohydrase $(200 \mathrm{~g} /$ ton $)+$ phytase $(50 \mathrm{~g} /$ ton $)$, respectively.

${ }^{\text {ab }}$ Provided the following quantities of minerals and vitamins per $\mathrm{kg}$ of complete diet: $\mathrm{Mn}(\mathrm{MnO}), 40.2 \mathrm{mg} ; \mathrm{Fe}\left(\mathrm{FeSO}_{4} \cdot \mathrm{H}_{2} \mathrm{O}\right), 90 \mathrm{mg}$; $\mathrm{Zn}(\mathrm{ZnO})$, $117.8 \mathrm{mg} ; \mathrm{Cu}\left(\mathrm{CuSO}_{4} \cdot 5 \mathrm{H}_{2} \mathrm{O}\right), 105 \mathrm{mg}$; I (KI), $42 \mathrm{mg}$; Se $\left(\mathrm{Na}_{2} \mathrm{SeO}_{3}\right), 36$ $\mathrm{mg}$; retinyl acetate, 10,500 IU; cholecalciferol, 1,650 IU; DL-alfatocopheryl acetate, $6 \mathrm{mg}$; menadione sodium bisulfite complex, $2 \mathrm{mg}$; niacin, $30 \mathrm{mg}$; vitamin $\mathrm{B}_{12}, 22 \mathrm{mg}$; thiamine, $1.2 \mathrm{mg}$; pyridoxine, $2.2 \mathrm{mg}$; riboflavin, $4 \mathrm{mg}$; pantothenic acid, $18 \mathrm{mg}$; choline chloride, $210 \mathrm{mg}$.

calculation of AID and SID of AA. The MC and Phy used for the current study were obtained from Uniquimica, Sao Paulo, Brazil. The MC blend contained: galactomannanase, $10 \%$; xylanase, $10 \%$; $\beta$-glucanase, $10 \%$; malted barley, $60 \% ; \alpha$-galactosidase, $10 \%$ and was added at $200 \mathrm{~g} /$ ton in the diet. The phytase used was fermented from Saccharomyces cerevisiae (KCCM 80051). Phytase 
(activity of 10,000 FTU/g) was added at $50 \mathrm{~g} /$ ton in the diet. All diets were supplemented with minerals and vitamins to meet or exceed recommended nutrient specification for growing pigs (Rostagno et al., 2011).

\section{Samples collection and chemical analyses}

Weaned piglets were fed reference corn dry-whey milkpowder diet for 10 days and subsequently were introduced to experimental diets. Following the 7-d adaptation period, feces and urine were quantitatively collected for 3 days for the determination of ATTD of nutrients. Pigs were weighted at the initial collection period of feces and urine $(8.8 \pm 1.1$ $\mathrm{kg}$ ) and at slaughter on ileal content collection $(9.9 \pm 1.3 \mathrm{~kg})$. The daily amount of feed provided to the pigs was calculated as 3 times the estimated requirement for maintenance energy (i.e., $197 \mathrm{kcal}$ of $\mathrm{ME} / \mathrm{kg}$ of BW0.60; $\mathrm{NRC}, 2012$ ) and provided in 2 equal meals at 0700 and 1700 h. Pigs were allowed ad libitum access to water throughout the experiment. Fecal samples were collected twice a day $(0800$ and $1800 \mathrm{~h})$, weighed and stored in a freezer at $-10^{\circ} \mathrm{C}$. Urine was collected in plastic containers with $5 \mathrm{~mL}$ of $10 \% \quad \mathrm{H}_{2} \mathrm{SO}_{4}$ to minimize the $\mathrm{NH}_{3}$ volatilization. The volume was weighed daily, and a $10 \%$ aliquot was removed and refrigerated at $-10^{\circ} \mathrm{C}$. At the end of the collection, the feces were homogenized, sub sampled (about $300 \mathrm{~g}$ ) and dried in a forced air oven at $60^{\circ} \mathrm{C}$ for $72 \mathrm{~h}$. Diet, BR, and feces sample were ground to pass a $1 \mathrm{~mm}$ sieve, and subjected to crude protein (CP) analysis $(\mathrm{N} \times 6.25)$ using Kjeldahl procedures (analyzer model Tecnal TE/036/1). Standard AOAC (2005) procedures were used for dry matter (DM) (930.15), fat (2003.06), ash (942.05) and AAs (994.12 alternative 1 and 3) determination. The acid detergent fiber (ADF) and neutral detergent fiber (NDF) contents in diets were determined according to the method of Goering and Van Soest (1970). The AA content was determined using an analyzer 1260 Infinity LCs (Agilent Technologies, Santa Clara, CA, USA). Tryptophan was not determined. Cysteine and glycine were not detected. All analyses were done in duplicate. Gross energy (GE) of $\mathrm{BR}$, diets, feces and freeze-dried urine samples was determined using adiabatic oxygen bomb calorimeter (IKA C5000, Staufen, Germany) with benzoic acid used as the calibration standard. Two days prior to slaughter animals were fed low protein reference diet containing $5 \%$ casein as a sole source of protein to determine the endogenous AA losses, and experimental diets where $30 \%$ of the reference diet was replaced by test ingredient with or without enzymes. At the end of the trial, animals were slaughtered and digesta samples were collected from the terminal ileum (about $30 \mathrm{~cm}$ segment). Before slaughter, pigs were weighed and then given an intramuscular injection of acepromazine maleate $(0.3 \mathrm{mg} / \mathrm{kg}$ of BW $)$ mixed in a single syringe with $15 \mathrm{mg}$ of ketamine hydrochloride/ $\mathrm{kg}$ of BW as a preanesthetic tranquilizer. Once tranquilized sufficiently, approximately $20 \mathrm{mg}$ of thiopental $/ \mathrm{kg}$ of $\mathrm{BW}$ was administered by intracardiac injection. Ileal content samples were freeze-dried, ground and analyzed for DM, AA, and $\mathrm{Cr}_{2} \mathrm{O}_{3}$. Chromium was analyzed using atomic absorption spectrophotometry (UV- 1201, Shimadzu, Kyoto, Japan), according to Willians et al. (1962).

\section{Calculation and statistical analyses}

ATTD of nutrients was determined by the total collection method as described by Woyengo et al. (2010) using the following equations:

$$
\operatorname{ATTD}(\%)=100 \times\left(\mathrm{NI}-\mathrm{NO}_{\text {feces }}\right) / \mathrm{NI}
$$

where: NI is the nutrient or energy intake (MJ) and $\mathrm{NO}_{\text {feces }}$ is the nutrient or energy output in feces (MJ).

The digestible energy (DE) and ME values of the BR were determined using the following equations:

$\mathrm{DE}(\mathrm{MJ} / \mathrm{kg})=[($ total tract GE digestibility for BR, \% $)$ $\times(\mathrm{GE}$ value of $\mathrm{BR}, \mathrm{MJ} / \mathrm{kg}) / 100]$

and

$$
\begin{aligned}
& \mathrm{ME}(\mathrm{MJ} / \mathrm{kg})= {[(\mathrm{GE} \text { retention for the ingredient, \%) }} \\
&\times(\mathrm{GE} \text { values in ingredient, } \mathrm{MJ} / \mathrm{kg}) / 100]
\end{aligned}
$$

The GE retention was calculated using the following equation:

$$
\begin{aligned}
& \text { GE retention }(\%) \\
& =100 \times\left[\left(\mathrm{GE} \mathrm{I}-\mathrm{GE} \mathrm{O}_{\text {feces }}-\mathrm{GE} \mathrm{O}_{\text {urine }}\right) / \mathrm{GE} \mathrm{I}\right],
\end{aligned}
$$

where: GE I is the GE intake $(\mathrm{MJ} / \mathrm{kg})$ and $\mathrm{GE} \mathrm{O}_{\text {feces }}$ is the energy output in feces $(\mathrm{MJ} / \mathrm{kg})$, and $\mathrm{GE} \mathrm{O}_{\text {urine }}$ is the energy output in urine $(\mathrm{MJ} / \mathrm{kg})$.

Apparent ileal AA digestibility were calculated using formula (Nyachoti et al., 1997):

$$
\begin{array}{r}
\operatorname{AID}(\%)=100-\left[100 \times\left(\mathrm{AA}_{\text {digesta }} \times \mathrm{Cr}_{2} \mathrm{O}_{3 \text { diet }}\right)\right. \\
\left./\left(\mathrm{AA}_{\text {diet }} \times \mathrm{Cr}_{2} \mathrm{O}_{3 \text { digesta }}\right)\right]
\end{array}
$$

where $\mathrm{AA}_{\text {diet }}$ and $\mathrm{AA}_{\text {digesta }}$ are the concentrations $(\mathrm{mg} / \mathrm{kg}$ $\mathrm{DM}$ ) of $\mathrm{AA}$ in the diet and digesta, respectively, and $\mathrm{Cr}_{2} \mathrm{O}_{3 \text { diet }}$ and $\mathrm{Cr}_{2} \mathrm{O}_{3 \text { digesta }}$ are the concentrations ( $\mathrm{mg} / \mathrm{kg} \mathrm{DM}$ ) of the indigestible marker in the diet and digesta, respectively. Apparent ileal AA digestibility were standardized using average values for basal endogenous AA losses calculated using formula (Nyachoti et al., 1997):

$$
\mathrm{AA}_{\mathrm{EL}}(\mathrm{g} / \mathrm{kg})=\mathrm{AA}_{\text {digesta }} \times\left(\mathrm{Cr}_{2} \mathrm{O}_{3 \text { diet }} / \mathrm{Cr}_{2} \mathrm{O}_{3 \text { digesta }}\right)
$$

where $\mathrm{AA}_{\mathrm{EL}}=$ average endogenous AA loss in $(\mathrm{g} / \mathrm{kg}$ of 
DM).

Determined endogenous ileal AA losses $(\mathrm{g} / \mathrm{kg}$ of dry matter intake) were as follow: arginine, 0.50; histidine, 0.31 ; isoleucine, 0.50 ; leucine, 0.80 ; lysine, 0.41 ; methionine, 0.21; phenilanine, 0.52; threonine, 0.93; valine, 0.67 ; alanine, 0.76; asparagine, 0.60 ; glutamine, 1.13; proline, 0.95 ; serine, 0.99 , and tyrosine, $0.35 \mathrm{~g} / \mathrm{kg}$.

SID was calculated according to equation below as described by Opapeju (2006):

$$
\operatorname{SID}(\%)=\left[\mathrm{AID}+\left(\mathrm{AA}_{\mathrm{EL}} / \mathrm{AA}_{\text {diet }}\right)\right] \times 100
$$

Data was subjected to Analysis of Variance using the Mixed Procedure of SAS (2002) (SAS Software Release 9.2, SAS Institute, Inc., Cary, NC, USA). The homogeneity of variances was evaluated by Hartley test and the normality of residuals by the Shapiro-Wilk test (UNIVARIATE procedure). The statistical model used was:

$$
\mathrm{Y}_{\mathrm{ij}}=\mu+\mathrm{a}_{\mathrm{i}}+\mathrm{b}_{\mathrm{j}}+\left(\mathrm{a}_{\mathrm{i}} \times \mathrm{b}_{\mathrm{j}}\right)+\mathrm{e}_{\mathrm{ij}}
$$

where $Y_{i j}=$ variable response of piglets fed MC (i) and phytase $(j) ; \mu=$ overall effect of average; $a i=$ fixed effect of $\mathrm{MC} ; \mathrm{bj}=$ fixed effect of phytase; $\left(\mathrm{a}_{\mathrm{i}} \times \mathrm{b}_{\mathrm{j}}\right)=$ interaction of $\mathrm{MC}$ and phytase; $\mathrm{e}_{\mathrm{ij}}=$ error term (residue).

\section{RESULTS AND DISCUSSION}

The chemical composition of BR and experimental diets are presented in Table 2 and 3. CP content $(7.75 \%)$ and AA

\begin{tabular}{|c|c|c|c|c|c|c|}
\hline \multirow{2}{*}{ Item $(\%)$} & \multirow{2}{*}{$\frac{\text { Ingredient }}{\mathrm{BR}}$} & \multicolumn{5}{|c|}{ Diets $^{1}$} \\
\hline & & $\mathrm{R}$ & $\mathrm{BR}$ & $\mathrm{BR}+\mathrm{MC}$ & BR+Phy & $\mathrm{BR}+\mathrm{MC}+\mathrm{Phy}$ \\
\hline Dry matter & 86.97 & 90.25 & 89.27 & 89.44 & 89.39 & 89.31 \\
\hline GE $(\mathrm{MJ} / \mathrm{kg})$ & 13.08 & 14.46 & 14.33 & 14.40 & 13.91 & 14.08 \\
\hline Crude protein & 7.75 & 10.78 & 9.75 & 9.69 & 9.61 & 9.59 \\
\hline Ash & 1.18 & 5.88 & 4.24 & 4.64 & 4.47 & 4.78 \\
\hline Crude fiber & 0.72 & - & - & - & - & - \\
\hline $\mathrm{NDF}$ & 4.81 & - & - & - & - & - \\
\hline $\mathrm{ADF}$ & 3.22 & - & - & - & - & - \\
\hline Fat & 0.78 & - & - & - & - & - \\
\hline
\end{tabular}

Table 2. Analyzed composition of broken rice and experimental diets used for the apparent total tract digestibility (ATTD) determination

NDF, neutral detergent fiber; ADF, acid detergent fiber.

${ }^{1} \mathrm{R}$, reference diet; $\mathrm{BR}$, broken rice; MC, multicarbohydrase; Phy, phytase.

Table 3. Analyzed amino acids content of broken rice and experimental diets used for the apparent (AID) and standardized (SID) ileal

\begin{tabular}{|c|c|c|c|c|c|c|}
\hline \multirow{2}{*}{ Item $(\%)$} & \multirow{2}{*}{$\frac{\text { Ingredient }}{\mathrm{BR}}$} & \multicolumn{5}{|c|}{$\operatorname{Diets}^{1}$} \\
\hline & & $\mathrm{R}$ & $\mathrm{BR}$ & $\mathrm{BR}+\mathrm{MC}$ & BR+Phy & BR+MC+Phy \\
\hline \multicolumn{7}{|c|}{ Indispensable amino acid } \\
\hline Arginine & 0.64 & 0.15 & 0.28 & 0.29 & 0.27 & 0.29 \\
\hline Histidine & 0.20 & 0.13 & 0.15 & 0.15 & 0.14 & 0.15 \\
\hline Isoleucine & 0.33 & 0.24 & 0.25 & 0.26 & 0.26 & 0.25 \\
\hline Leucine & 0.63 & 0.46 & 0.51 & 0.50 & 0.49 & 0.49 \\
\hline Lysine & 0.30 & 0.38 & 0.36 & 0.35 & 0.35 & 0.34 \\
\hline Methionine & 0.18 & 0.12 & 0.13 & 0.13 & 0.13 & 0.14 \\
\hline Phenylalanine & 0.37 & 0.36 & 0.42 & 0.41 & 0.40 & 0.41 \\
\hline Threonine & 0.33 & 0.23 & 0.25 & 0.25 & 0.24 & 0.23 \\
\hline Valine & 0.54 & 0.33 & 0.37 & 0.37 & 0.37 & 0.36 \\
\hline \multicolumn{7}{|c|}{ Dispensable amino acid } \\
\hline Alanine & 0.45 & 0.16 & 0.24 & 0.25 & 0.23 & 0.24 \\
\hline Aspartic acid & 0.81 & 0.39 & 0.51 & 0.52 & 0.49 & 0.50 \\
\hline Cysteine & 0.07 & 0.02 & 0.03 & 0.03 & 0.03 & 0.03 \\
\hline Glutamic acid & 1.25 & 0.94 & 1.02 & 1.01 & 0.98 & 0.98 \\
\hline Glycine & 0.35 & 0.09 & 0.16 & 0.17 & 0.16 & 0.16 \\
\hline Proline & 0.40 & 0.45 & 0.41 & 0.40 & 0.40 & 0.39 \\
\hline Serine & 0.41 & 0.28 & 0.32 & 0.32 & 0.30 & 0.31 \\
\hline Tyrosine & 0.36 & 0.25 & 0.29 & 0.29 & 0.27 & 0.27 \\
\hline Total AA & 7.64 & 4.98 & 5.71 & 5.70 & 5.53 & 5.54 \\
\hline
\end{tabular}
digestibility determination

${ }^{1} \mathrm{R}$, reference diet; BR, broken rice; MC, multicarbohydrase; Phy, phytase. 
profile of $\mathrm{BR}$ are similar to the values proposed by Rostagno et al. (2011) and NRC (2012). The contents of $\mathrm{NDF}, \mathrm{ADF}$, and crude fiber of the BR are lower than previously reported in the literature. The compositional variability of BR used in the present experiment, and BR reported in literature, reflects the differences which depend of the manufacturing processes. There was no $(p>0.05)$ interaction between enzymes on nutrient and energy digestibility of BR (Table 4). In comparison to treatment without enzymes, Phy supplementation improved digestibility of DM, while MC improved digestibility of CP $(p<0.01)$, digestible $(p<0.01)$ and $\operatorname{ME}(p=0.02)$. The results of apparent digestibility of $\mathrm{CP}$ in $\mathrm{BR}$ without enzyme supplementation were $5.7 \%$ and $14.5 \%$ lower than those described by Apolônio et al. (2003) and Rostagno et al. (2011), respectively. It demonstrates that the utilization of BR protein by young pigs ( $9 \mathrm{~kg}$ average BW) is limited due to underdeveloped gastrointestinal tract when compared to the older and heavier pigs (20 kg and more) commonly used in an animal model to determine nutrients digestibility and widely presented in the literature. Results showed that the BR can be alternative energy source for pigs. Positive results on the GE digestibility with $\mathrm{MC}$ supplementation were demonstrated in this experiment, indicating that the enzyme could be a viable additive to BR-based diets for postweaned piglets. Some studies demonstrated benefits of BR showing that weaned pigs fed with rice-based diets had greater AID of GE, organic matter, fat, and ADFI compared with corn-based diets (Hongtrakul et al., 1998; Li et al., 2002; Mateos et al., 2006; Menoyo et al., 2011). According to Hongtrakul et al. (1998) in the United States, corn is the predominant energy source used in swine diets. However, in Asia and other parts of the world, many other carbohydrate sources are more available and less expensive.

$\mathrm{BR}$, in comparison to the other cereals, contains more starch and less fiber which is favorable for diets for young piglets (Kim et al., 2007; Vicente et al., 2008) but its use in pig diets is limited due to unforeseen, small and seasonal supply on the market, and inconsistent nutritional profile compared to conventional ingredients, like soybean and corn. The lack of product on the market might also contribute to the limited research on BR for animal nutrition. According to Teixeira (1997) there are some controversy related to dietary inclusion of BR for pigs and might be associated with different degree of the product cleanliness. The same author reported that BR is considered a byproduct, thus its batch to batch quality might not be uniform and some contaminants as rice hulls, barnyard grass seeds (Equinocloa spp.) and some Aeschynomene spp. contributes to elevated level of ash and fiber fraction.

Despite the BR has a good nutritional composition and potential to be an alternative to corn in diets for growing and finishing pigs, few studies analyzing AA digestibility in BR with piglets have been reported in the literature. The results of current study revealed overall good AA digestibility of BR for young piglets (Tables 5 and 6). Most of the SID of AA of BR values presented in Nutrient Requirements of Swine (NRC, 2012) is higher than those determined in the current study: arginine, $89 \%$ vs $84 \%$; histidine, $84 \%$ vs $77 \%$; isoleucine, $81 \%$ vs $79 \%$; leucine, $83 \%$ vs $79 \%$; lysine, $77 \%$ vs $78 \%$; methionine, $85 \%$ vs $81 \%$; threonine, $76 \%$ vs $65 \%$; valine, $78 \%$ vs $81 \%$, respectively. It is suggested that postweaned piglets are less able to harness the $\mathrm{AA}$ in $\mathrm{BR}$, compared with the growing-finishing phases.

The results of the study showed that Phy supplementation improved the SID of histidine $(p=0.05)$, arginine, leucine, lysine, valine, alanine, and proline $(p<0.05)$ of BR, however the difference were not observed when diets were supplemented with MC. There was not interaction between Phy and $\mathrm{MC}$ on the BR nutrient digestibilities $(p>0.05)$. Similarly, the positive effect of dietary inclusion of Phy on AA digesitibility and energy utilization, in addition to improved $\mathrm{P}$ utilization, was demonstrated in broiler study by Ravindran et al. (2000). The enzymes can be more efficient on rice due to the morphology of the grain which has smaller size of the starch granules, and contains less amylose and less lipid/amylose complex in comparison to corn (Tester et al., 2004). According to Fireman and Fireman (1998), positive or negative results from the exogenous enzymes use, appeared to stem from of the substrate concentration in the

Table 4. Apparent total tract digestibility (ATTD) of nutrients and energy for broken rice, without or with enzymes for postweaned piglets

\begin{tabular}{|c|c|c|c|c|c|c|c|c|}
\hline \multirow{2}{*}{ Item $(\%)$} & \multicolumn{4}{|c|}{ Treatments $^{1}$} & \multirow{2}{*}{ SEM } & \multicolumn{3}{|c|}{ p-values } \\
\hline & $\mathrm{BR}$ & $\mathrm{BR}+\mathrm{MC}$ & BR+Phy & $\mathrm{BR}+\mathrm{MC}+\mathrm{Phy}$ & & $\mathrm{MC}$ & Phy & MC+Phy \\
\hline Dry matter & 93.72 & 93.55 & 95.90 & 96.88 & 0.664 & 0.752 & 0.044 & 0.653 \\
\hline Crude protein & 77.89 & 81.83 & 77.81 & 84.82 & 1.069 & 0.008 & 0.433 & 0.408 \\
\hline Digestible energy $(\mathrm{MJ} / \mathrm{kg})^{*}$ & 15.67 & 16.11 & 15.70 & 16.37 & 25.411 & 0.007 & 0.441 & 0.531 \\
\hline Metabolizable energy $(\mathrm{MJ} / \mathrm{kg})^{*}$ & 15.57 & 15.94 & 15.59 & 16.15 & 24.455 & 0.024 & 0.562 & 0.604 \\
\hline $\mathrm{ME} / \mathrm{GE}$ & 90.04 & 92.17 & 90.11 & 93.37 & 0.592 & 0.023 & 0.562 & 0.605 \\
\hline
\end{tabular}

SEM, standard error of mean.

${ }^{1} \mathrm{BR}$, broken rice; MC, multicarbohydrase; Phy, phytase.

* Calculate in, \% DM; ME/GE, metabolizable:gross energy. 
Table 5. Apparent ileal digestibility (AID) of amino acids for broken rice, without or with enzymes, for postweaned piglets

\begin{tabular}{|c|c|c|c|c|c|c|c|c|}
\hline \multirow{2}{*}{ Item $(\%)$} & \multicolumn{4}{|c|}{ Treatments $^{1}$} & \multirow{2}{*}{ SEM } & \multicolumn{3}{|c|}{ p-values } \\
\hline & $\mathrm{BR}$ & $\mathrm{BR}+\mathrm{MC}$ & BR+Phy & $\mathrm{BR}+\mathrm{MC}+\mathrm{Phy}$ & & $\mathrm{MC}$ & Phy & MC+Phy \\
\hline \multicolumn{9}{|l|}{ Indispensable AA } \\
\hline Arginine & 66.27 & 66.38 & 76.55 & 75.39 & 1.846 & 0.873 & 0.009 & 0.847 \\
\hline Histidine & 62.62 & 73.92 & 73.21 & 74.10 & 1.671 & 0.040 & 0.066 & 0.074 \\
\hline Isoleucine & 59.63 & 60.64 & 61.68 & 60.01 & 1.471 & 0.919 & 0.827 & 0.679 \\
\hline Leucine & 70.02 & 70.14 & 78.89 & 78.60 & 1.517 & 0.973 & 0.003 & 0.936 \\
\hline Lysine & 66.26 & 66.45 & 74.62 & 75.63 & 1.545 & 0.816 & 0.003 & 0.874 \\
\hline Methionine & 70.99 & 71.27 & 74.91 & 74.48 & 1.401 & 0.980 & 0.240 & 0.905 \\
\hline Phenylalanine & 72.14 & 76.50 & 76.16 & 73.84 & 1.266 & 0.701 & 0.798 & 0.220 \\
\hline Threonine & 49.24 & 49.72 & 50.90 & 49.61 & 1.340 & 0.891 & 0.793 & 0.764 \\
\hline Valine & 63.01 & 65.19 & 72.29 & 70.42 & 1.586 & 0.957 & 0.024 & 0.495 \\
\hline \multicolumn{9}{|l|}{ Dispensable AA } \\
\hline Alanine & 50.94 & 55.69 & 63.79 & 62.26 & 2.107 & 0.677 & 0.021 & 0.421 \\
\hline Aspartic acid & 61.77 & 63.76 & 64.60 & 65.24 & 1.413 & 0.668 & 0.484 & 0.825 \\
\hline Glutamine & 66.71 & 74.79 & 73.10 & 73.02 & 1.456 & 0.169 & 0.417 & 0.160 \\
\hline Proline & 62.34 & 62.23 & 68.55 & 68.84 & 1.387 & 0.973 & 0.024 & 0.940 \\
\hline Serine & 40.44 & 40.33 & 43.34 & 43.28 & 1.563 & 0.980 & 0.391 & 0.994 \\
\hline Tyrosine & 74.39 & 76.22 & 76.31 & 75.46 & 1.050 & 0.829 & 0.800 & 0.561 \\
\hline
\end{tabular}

SEM, standard error of mean; AA, amino acid.

${ }^{1} \mathrm{BR}$, broken rice; MC, multicarbohydrase; Phy, Phytase.

diet, the antagonism between enzymes, the enzyme concentration or by animal category tested. Since the supplemental enzyme has affinity by the substrate, increases on digestibility could be observed (Zijlstra et al., 2004).

In conclusion, the energy and nutrients digestibility of $\mathrm{BR}$, without enzymes, indicates lower values than those reported in the literature are acquired from pigs in the later stages of growth. The MC enzyme effectively increase the energy and protein digestibility of BR, while phytase improved apparent digestibility of dry matter and the SID of arginine, histidine, leucine, lysine, alanine, and proline.

Table 6. Standardized ileal digestibility (SID) of amino acids for broken rice, without or with enzymes, for postweaned piglets

\begin{tabular}{|c|c|c|c|c|c|c|c|c|}
\hline \multirow{2}{*}{ Item $(\%)$} & \multicolumn{4}{|c|}{ Treatments $^{1}$} & \multirow{2}{*}{ SEM } & \multicolumn{3}{|c|}{ p-values } \\
\hline & $\mathrm{BR}$ & $\mathrm{BR}+\mathrm{MC}$ & BR+Phy & BR+MC+Phy & & $\mathrm{MC}$ & Phy & MC+Phy \\
\hline \multicolumn{9}{|l|}{ Indispensable AA } \\
\hline Arginine & 84.14 & 83.62 & 94.96 & 92.77 & 1.846 & 0.680 & 0.007 & 0.799 \\
\hline Histidine & 76.94 & 88.17 & 87.90 & 88.54 & 1.671 & 0.045 & 0.054 & 0.070 \\
\hline Isoleucine & 79.16 & 80.01 & 80.80 & 80.05 & 1.471 & 0.986 & 0.796 & 0.806 \\
\hline Leucine & 78.95 & 79.10 & 88.08 & 87.83 & 1.517 & 0.984 & 0.003 & 0.938 \\
\hline Lysine & 77.54 & 78.17 & 86.13 & 87.54 & 1.545 & 0.693 & 0.003 & 0.879 \\
\hline Methionine & 80.76 & 80.78 & 87.65 & 83.88 & 1.401 & 0.530 & 0.107 & 0.526 \\
\hline Phenylalanine & 84.33 & 88.97 & 90.66 & 86.33 & 1.266 & 0.955 & 0.490 & 0.106 \\
\hline Threonine & 64.97 & 65.74 & 67.91 & 66.74 & 1.340 & 0.947 & 0.506 & 0.742 \\
\hline Valine & 81.05 & 83.06 & 90.24 & 88.85 & 1.586 & 0.915 & 0.020 & 0.567 \\
\hline \multicolumn{9}{|l|}{ Dispensable AA } \\
\hline Alanine & 61.29 & 65.88 & 74.48 & 72.66 & 2.107 & 0.721 & 0.018 & 0.411 \\
\hline Aspartic acid & 73.47 & 75.29 & 76.73 & 77.24 & 1.413 & 0.704 & 0.400 & 0.831 \\
\hline Glutamine & 77.83 & 85.96 & 84.68 & 84.55 & 1.456 & 0.169 & 0.341 & 0.156 \\
\hline Proline & 85.32 & 85.62 & 92.03 & 92.95 & 1.387 & 0.814 & 0.015 & 0.906 \\
\hline Serine & 71.59 & 71.79 & 77.18 & 75.81 & 1.563 & 0.863 & 0.168 & 0.817 \\
\hline Tyrosine & 86.50 & 88.22 & 89.13 & 88.37 & 1.050 & 0.833 & 0.545 & 0.590 \\
\hline
\end{tabular}

SEM, standard error of mean; AA, amino acid.

${ }^{1} \mathrm{BR}$, broken rice; MC, multicarbohydrase; Phy, Phytase.

\section{CONFLICT OF INTEREST}

We certify that there is no conflict of interest with any financial organization regarding the material discussed in 
the manuscript.

\section{ACKNOWLEDGMENTS}

The authors gratefully acknowledge the The Sao Paulo Research Foundation (FAPESP) by financial support in the Project 2012/00517-0 and Coordination for the Improvement of Higher Education Personnel (CAPES) for scholarship.

\section{REFERENCES}

AOAC (Association of Official Analytical Chemists). 2005. Official Methods of Analysis of the Association of Official Analytical Chemists. 18th edn. Gaithersburg, MD, USA.

Apolônio, L. R., J. L. Donzele, R. F. M. Oliveira, A. V. C. Souza, F. C. O. Silva, and S. Bünzen. 2003. Ileal amino acid digestibility of some ingredients, determined by the simple T-cannula technique with pigs. Brazilian Anim. Sci. 32:605-614.

Fireman, F. A. T. and A. K. B. A. T. Fireman. 1998. Enzymes in pig diets. Ciência Rural 28:173-178.

Goering, H. K. and P. J. Van Soest. 1970. Forage fiber analysis (apparatus, reagents, procedures and some applications). United States Department of Agriculture, Washington DC, USA.

Hongtrakul, K., R. D. Goodband, K. C. Behnke, J. L. Nelssen, M. D. Tokach, J. R. Bergström, W. B. Nessmith, and I. H. Kim. 1998. The effects of extrusion processing of carbohydrate sources on weanling pig performance. J. Anim. Sci. 76:30343042.

Kim, J. C., P. H. Simmins, B. P. Mullan, and J. R. Pluske. 2005. The digestible energy value of wheat for pigs, with special reference to the post-weaned animal. Anim. Feed. Sci. Technol. 122: 257-287.

Kim, J. C., B. P. Mullan, D. J. Hampson, M. M. J. A. Rijnen, and J. R. Pluske. 2007. The digestible energy and net energy content of two varieties of processed rice in pigs of different body weight. Anim. Feed Sci. Technol. 134:316-325.

Li, D., D. F. Zhang, X. S. Piao, I. K. Han, C. J. Yang, J. B. Li, and J. H. Lee. 2002. Effects of replacing corn with Chinese brown rice on growth performance and apparent fecal digestibility of nutrients in weaning pigs. Asian Australas. J. Anim. Sci. 15:1191-1197.

Mateos, G. G., F. Martin, M. A. Latorre, B. Vicente, and R. Lazaro. 2006. Inclusion of oat hulls in diets for young pigs based on cooked maize or cooked rice. Anim. Sci. 82:57-63.
Menoyo, D., M. P. Serrano, V. Barrios, D. G. Valencia, R. Lazaro, J. Argente, and G. G. Mateos. 2011. Cereal type and heat processing of the cereal affect nutrient digestibility and dynamics of serum insulin and ghrelin in weanling pigs. J. Anim. Sci. 89:2793-2800.

NRC. 2012. Nutrient Requirements of Swine. 11th revised edn. National Academies Press, Washington, DC, USA.

Nyachoti, C. M., C. F. de Lange, and H. Schulze. 1997. Estimating endogenous amino acid flows at the terminal ileum and true ileal amino acid digestibilities in feedstuffs for growing pigs using the homoarginine method. J. Anim. Sci. 75:3206-3213.

Opapeju, F. O., A. Golian, C. M. Nyachoti, and L. D. Campbell. 2006. Amino acid digestibility in dry extruded-expelled soybean meal fed to pigs and poultry. J. Anim. Sci. 84:11301137.

Ravindran, V., S. Cabahug, G. Ravindran, P. H. Selle, and W. L. Bryden. 2000. Response of broiler chickens to microbial phytase supplementation as influenced by dietary phytic acid and non-phytate phosphorous levels. II. Effects on apparent metabolisable energy, nutrient digestibility and nutrient retention. Br. Poult. Sci. 41:193-200.

Rostagno, H. S., L. F. T. Albino, J. L. Donzele, P. C. Gomes, and R. F. Oliveira. 2011. Brazilian Tables for Broilers and Pigs. Food Composition and Nutritional Requirements. 3rd edn. Viçosa: MG, Brazil. 252 p.

SAS. 2002. SAS/STAT User Guide, Release 8.0, SAS Institute Inc., Cary, NC, USA.

Slominski, B. A. 2011. Recent advances in research on enzymes for poultry diets. Poult. Sci. 90:2013-2023.

Teixeira, A. S. 1997. Food and Animal Feed. 4th edn. Lavras: UFLA/FAEPE, MG, Brazil. 402 p.

Tester, R. F., J. Karkalas, and X. Qi. 2004. Starch - Composition, fine structure and architecture. J. Cereal Sci. 39:151-165.

Vicente, B., D. G. Valencia, M. Perez-Serrano, R. Lazaro, and G. G. Mateos. 2008. The effects of feeding rice in substitution of corn and the degree of starch gelatinization of rice on the digestibility of dietary components and productive performance of young pigs. J. Anim. Sci. 86:119-126.

Williams, C. H., D. J. David, and O. Iismaa. 1962. The determination of chromic oxide in faeces samples by atomic absorption spectrophotometry. J. Agric. Sci. 59:381-385.

Woyengo, T. A., E. Kiarie, and C. M. Nyachoti. 2010. Energy and amino acid utilization in expeller-extracted canola meal fed to growing pigs. J. Anim. Sci. 88:1433-1441.

Zijlstra, R. T., S. Li, A. Owusu-Asiedu, P. H. Simmins, and J. F. Patience. 2004. Effect of carbohydrase supplementation of wheat- and canola-meal-based diets on growth performance and nutrient digestibility in group-housed weaned pigs. Can. J. Anim. Sci. 84:689-695. 